\title{
INTESTINAL PARASITES INFECTIONS IN HOSPITALIZED AIDS PATIENTS IN KINSHASA, Democratic Republic of CONGO
}

\author{
WUMBA R.*, LONGO-MBENZA B.**, MANDINA M.**, ODIO WOBIN T.*, BILIGUI S.****, \\ SALA J.*, BRETON J.****,****** \& THELLIER M.***,*****
}

\section{Summary:}

To determine the prevalence and the species spectrum of intestinal parasites (IP) involved in hospitalized AIDS patients, a prospective observational and cross-sectional study was carried out in the four main hospitals in Kinshasa, Democratic Republic of the Congo. From November 2006 through September 2007, a single stool sample was collected from 175 hospitalized AIDS patients older than 15 years. Parasites were detected by light microscopy, including Ziehl-Neelsen, Fungi-Fluor, modified trichrome stains, and by immunofluorescence antibody tests and PCR for species diagnosis of microsporidia. At baseline, 19 patients (10.8\%) were under antiretroviral therapy and $156(89.2 \%)$ were eligible for ART. The main diagnosis for justifying hospitalization was intestinal infection associated with diarrhea in 87 out of 175 (49.7\%) 47 out of $175(26.9 \%)$ were found to harbor an IP, and 27 out of 175 (15.4\%) were infected with at least one opportunistic IP (OIP). Prevalence rate for OIP were $9.7 \%, 5.1 \%, 1.7 \%$ and $0.6 \%$ for Cryptosporidium sp., Enterocytozoon bieneusi, Isospora belli and Encephalitozoon intestinalis respectively. Considering patients with diarrhea only, prevalence rate were $12.6 \%, 4.6 \%, 3.4 \%$ and $1.1 \%$ respectively. The other IP observed were Entamoeba histolytica/Entamoeba dispar in nine cases (5.1\%), Ascaris lumbricoïles in seven cases $(4.0 \%)$, Giardia intestinalis in three cases (1.7\%), hookworm in two cases (1.1\%) and Trichiuris trichiura, Enterobius vermicularis, Schistosoma mansoni in one patient each (0.6\%). No significant relationship was established between any individual IP and diarrhea. These results underline the importance of OIP in symptomatic AIDS patients regardless of diarrhea at the time of the hospitalisation, and showed that routine microscopic examination using stains designed for Cryptosporidium spp. or the microsporidia should be considered due to the absence of clinical markers.

KEY WORDS : AIDS, microsporidia, cryptosporidia, intestinal parasite, epidemiology, diagnosis, Central Africa.

\footnotetext{
* Department of Tropical Medicine, Infectious Diseases, Division of Parasitology, University of Kinshasa, DR of the Congo.

**: Department of Internal Medicine, Division of Cardiology and Pathophysiology, University of Kinshasa, DR of the Congo.

*** AP-HP, Groupe hospitalier Pitié-Salpêtrière, Service de Parasitologie-Mycologie, Paris, France.

***** Université Pierre et Marie Curie, UMR-S 945 INSERM/Paris 6, Boulevard de l'Hôpital, Paris, France.

****** Present address: ICSN, CNRS UPR 2301, 91190Gif-sur-Yvette, France.

Correspondence : Roger Wumba, Département de Médecine Tropicale, Maladies Infectieuses et Parasitaires, Service de Parasitologie, Cliniques Universitaires de Kinshasa, Faculté de Médecine, Université de Kinshasa à LEMBA, BP 747, RD Congo.

Tel.: +243 897376133 / 813885291 (RDC); +33 (0)6 60263162

(France)

E-mail: rogerwumba@yahoo.fr
}

Résumé : INFECTIONS PARASITAIRES INTESTINALES DE PATIENTS ATTEINTS DE SIDA, hospitalisés à Kinshasa, République Démocratique DU CONGO

Afin de déterminer la prévalence et le spectre étiologique des infections parasitaires (IP) du tube digestif chez les sujets atteints de SIDA hospitalisés à Kinshasa, République Démocratique du Congo (RDC), une étude prospective, transversale et observationnelle a été réalisée dans les quatre principaux hôpitaux de la ville. De novembre 2006 à septembre 2007, des échantillons de selles de 175 patients hospitalisés, âgés de plus de 15 ans et au stade de SIDA de l'infection par le VIH, ont été collectés. Les parasites ont été détectés en microscopie optique par un examen direct, une technique de concentration (méthode de Ritchie), une coloration de Ziehl-Neelsen modifiée, une coloration par le trichrome et une coloration par le Fungi Fluor. Le diagnostic d'espèce des microsporidies a été complété par une technique d'immunofluorescence utilisant des anticorps monoclonaux et par PCR. Au moment du diagnostic, 19 patients (10,8 \%) étaient sous traitement antirétroviral et 156 (89,2\%) étaient éligibles pour l'initiation du traitement antirétroviral. Le principal diagnostic ayant motivé l'hospitalisation a été la diarrhée infectieuse pour 87 patients $(49,7 \%) .47$ patients $(26,9 \%$ ) étaient porteurs d'au moins un parasite intestinal (PI) et $27(15,4 \%$ ) étaient infectés par au moins un parasite intestinal opportuniste (PIO). Les taux de prévalence des $\mathrm{PIO}$ étaient de $9,7 \%, 5,1 \%, 1,7 \%$ et $0,6 \%$ pour respectivement Cryptosporidium sp., Enterocytozoon bieneusi, Isospora belli et Encephalitozoon intestinalis. Si l'on considère les 87 patients diarrhéiques séparément, les taux de prévalences étaient alors de $12,6 \%, 4,6 \%, 3,4 \%$ et $1,1 \%$. Les autres Pl observés étaient Entamoeba histolytica/Entamoeba dispar dans neuf cas (5, $1 \%$, Ascaris lumbricoïdes dans sept cas (4.0\%), Giardia intestinalis dans trois cas (1,7\%), des ankylostomidés dans deux cas (1. $1 \%)$, et Trichiuris trichiura, Enterobius vermicularis et Schistosoma mansoni chez un patient chacun $(0,6 \%)$. Aucune association statistiquement significative avec la diarrhée n'a été retrouvée pour l'ensemble de ces parasites. Ces résultats montrent l'importance des PIO des patients symptomatiques hospitalisés au stade de SIDA de l'infection par le VIH en RDC, indépendamment de la présence d'une diarrhée au moment de l'hospitalisation. Du fait de l'absence de marqueur clinique spécifique, un diagnostic systématique de ces agents pathogènes avec les techniques appropriées est impératif chez ces patients particulièrement fragilisés.

MOTS CLÉS : SIDA, microsporidies, cryptosporidies, parasite intestinal, épidémiologie, diagnostic, Afrique Centrale. 


\section{INTRODUCTION}

D emocratic Republic of the Congo (DRC), located in the Central African region, is the third largest country on the African continent. With a population of more than seven million inhabitants, the capital Kinshasa (a city-province), located along the south bank of the Congo River, is also the third largest city in the whole continent after Lagos and Cairo (capitals of Nigeria and Egypt, respectively). AIDS pandemic is one of the major causes of death and morbidity in DRC. The HIV sera prevalence rate, according to the "Programme National Multisectoriel de Lutte contre le SIDA" (PNMLS) was estimated to be $4.04 \%$ for the whole country in 2006 (UNGASS 2007 report, available at: http://data. unaids.org/pub/Report/2008/democratic_republic_of_ congo_2008_country_progress_report_fr.pdf). However, due to successive political crises and war areas in different part of the country, great variations exist between provinces and even cities. The HIV positive rate were $3 \%, 10 \%$ and $27 \%$ for Kinshasa, Matadi, a western port city, and Kalemie another port city in the southeast, respectively (from UNDP, United Nations Development Program available at: http://www.undp.org. cd/News.aspx?newsID=64).

Since 2005, together with the improvement of the political situation, antiretroviral therapy (ART) became available and free for DRC citizens. This represents around 300,000 subjects for the whole country, and 13,000 for Kinshasa City alone (from PNMLS, 2007). It is of course a great advance in the fight against the AIDS pandemic, but it also raises many problems to reach the ultimate goal of giving an appropriate therapy for all. In Kinshasa, like elsewhere in Africa, this appears to be insufficient for many patients who died shortly after the diagnosis of AIDS (Konate et al., 1998; Lawn et al., 1897, Macpherson et al., 2008; Zachariah et al., 2006; Mzileni et al., 2008; Dillingham et al., 2009). Since the presence of diarrhea, found in nearly $50 \%$ of the patients at the time of the AIDS diagnosis, is associated with a great mortality rate, we can estimate that a part of them died because of intestinal parasites infections (Sewankambo et al., 2000). It is to underline that most often in such a situation, the ART cannot be initiated in good conditions because of severe weight loss and wasting syndrome. Considering that worrying situation the World Health Organization (WHO) had recently defines diarrhea wasting syndrome, along with positive HIV serology test, to be an AIDS-defining illness (Anonymous, 2006).

Several pathogens have been implicated with acute and chronic diarrhea in HIV disease in Africa. The most commonly reported include enteroaggregative Echerichia coli, Shigella spp., Rotavirus and intestinal parasites (IP), mainly Enterocytozoon bieneusi, Cryptosporidium spp., Isospora belli, and Giardia intestinalis (Gassama et al., 2001). Cryptosporidium spp., Ent. bieneusi, but also G. intestinalis are ubiquitous enteric protozoan pathogens that infect humans, domestic animals and wildlife worldwide. Both pathogens are significant causes of diarrhea and nutritional disorders in institutional and community settings. Since they are also significant waterborne pathogens, all diseases have a common link with poverty. In DRC, because of the lack of appropriate methods and trained technicians, IP prevalence rates were unknown before 2007 in HIV/AIDS patients. That situation was mostly the result of the complete disorganization of the sanitary system during the 1998-2004 war. In a recent article, we reported preliminary results, obtained in 50 hospitalized AIDS patients in Kinshasa, that confirmed the presence of these species, and especially Ent bieneusi (first identification of this species locally) in DRC (Wumba et al., 2007). In the present work, we carried out a larger prospective observational and cross-sectional study to determine the species spectrum, clinical presentation and prevalence of IP involved in AIDS patients hospitalized in the four main hospitals in Kinshasa.

\section{METHODS}

\section{STUDY POPULATION AND ENROLLMENT}

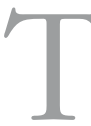
his study was designed to be cross-sectional with optional follow-up. Its main objective was to determine the prevalence of IP in AIDS patients at the moment of their hospitalization. Participants were recruited, between November 2006 and September 2007, from the four main hospitals in Kinshasa (DRC), the Cliniques Universitaires de Kinshasa (CUK) the main Teaching Hospital in DRC, two general hospitals, the Hôpital Général de Kinshasa and the Hôpital Général de Kintambo, and the Centre Médical Monkole, a specialized medical support centre for persons affected with HIV/AIDS. The criteria for inclusion in the study were documented HIV infection, presence of at least one AIDS-defining event including diarrhea wasting syndrome, age $>15$ years and the ability to provide informed consent. Each participant was interviewed using a standardized and structured questionnaire to collect demographic and clinical data and asked to provide at least one stool specimen, irrespective of symptoms, for detection of parasites. Diarrhea was defined on the basis of an average number of $>3$ loose or liquid stools within a $24 \mathrm{~h}$ period.

\section{ETHICAL CONSIDERATIONS}

The institutional review boards, the Kinshasa School of Medicine Ethics and Scientific Committee, approved the 
protocol and the study was done in compliance with the Helsinki declaration II. The aim and procedures of the study were explained, and an informed consent sheet was signed by each participant or a designated literate substitute when necessary.

\section{LABORATORY METHODS}

Biological analysis were performed in the Parasitology unit of the CUK in DRC for all the microscopic analysis and in the Parasitology-Mycology unit of the Groupe Hospitalier Universitaire de la Pitié-Salpêtrière (GHUPS) in Paris, France, for an external quality control and molecular biology analysis. At recruitment sites, stool samples were collected in plastic fecal collectors, immediately added with $10 \%$ buffered Formalin as a preservative and stored at room temperature. Every day except Sunday, stools were brought back to the CUK Parasitology unit laboratory and investigated for helminthes and unicellular parasites. The stool specimens were concentrated with the modified Ritchie formalin-ether method procedure (MRC) followed by microscopic examination (Ritchie et al., 1948). Cryptosporidium but also Isospora and Cyclospora species were detected using the modified Ziehl-Neelsen stain (MZNS) (Henriksen et al., 1981). Microsporidia were detected using both Weber's modified trichrome stain (MTS), and a Fungi-Fluor stain (FFS) (van Gool et al., 1994; Weber et al., 1992). Microsporidia species identification was performed using both an immunofluorescence antibody test using monoclonal antibodies (IFAT-Mab) directed against Ent bieneusi and Encephalitozoon intestinalis and specific PCR's (Thellier et al., 2001; Accoceberry et al., 1999; Alfa Cisse et al. 2002; Breton et al., 2007).

For all these techniques, an external Quality Control was performed in double-blinded conditions for all the positive samples and $20 \%$ of randomly selected negatives samples in the laboratory of the GHUPS. The microsporidia microscopy positive specimens were also processed in Paris, for DNA extraction using the QIAamp ${ }^{\circledR}$ DNA Stool MiniKit (QIAGEN, Courtaboeuf, France) following manufacturer's instructions as described elsewhere (Alfa Cisse et al., 2002; Breton et al., 2007). The region of DNA amplified by PCR was that encoded by the small subunit of the rRNA of Ent bieneusi and Enc intestinalis (Coyle et al., 1996). Common primers used to amplify both DNA species were INBI and PMP2 (Zhu et al., 1993). Specific primers pairs were INBI/BIENE for Ent bieneusi and INBI/EI500 for Enc intestinalis DNA (Zhu et al., 1993; Weiss et al., 1994; Zhu et al., 1993).

NuClEOTIDE SEQUENCING OF THE ITS REGION OF THE ENT. BIENEUSI RRNA GENE

Enterocytozoon bieneusi genotypes were analyzed by nucleotide sequencing of the ITS region of the rRNA gene. A PCR product of $508 \mathrm{bp}$, containing $122 \mathrm{bp}$ of the small-subunit rRNA, 243 bp of the ITS region, and $143 \mathrm{bp}$ of the large-subunit rRNA, was generated from Ent. bieneusi PCR samples using the primers MSP3 and MSP4B as previously described (Katzwinkel-Wladarsch et al., 1996). PCR products were purified using the Concert Rapid PCR kit (GIBCO-BRL) and sequenced in both directions using the ABI Big Dye Terminator kit (v1.1) and an ABI 3100 automated sequencer (Applied Biosystems). Sequencing three PCR products from the same sample in both directions controlled the sequence accuracy.

\section{NUCLEOTIDE SEQUENCE ACCESSION NUMBERS}

Nucleotide sequence of the ITS region of the rRNA gene of isolate RDC71 was deposited in GenBank under Accession Number FJ469914.

\section{STATISTICAL ANALYSIS}

Data were expressed as proportions (\%) for categorical variables and means with standard deviations for continuous variables. Differences were compared by the Chi-square test for proportions and by the Student t-test for continuous variables with results considered statistically significant for $p<0.05$. The kappa value was used to assess the concordance between the Congolese and the French laboratories.

\section{RESULTS}

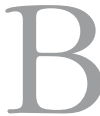

etween November 2006 and September 2007, a total of 175 hospitalized AIDS patients older than 15 years, entered the study. Of these, 89 were women (sex ratio $\mathrm{M} / \mathrm{F}=0.97$ ), and the median age was $41 \pm 14$ years, range (16-83 yrs). Men were 9 years older than women, $46 \pm 15$ years $v s 37 \pm 12$ years $(\mathrm{p}<0.001)$. A great part of the subjects, 65 of 175 (37.1\%) were unemployed with an equal proportion of men 34 $(52.3 \%)$ and women 31 (47.7\%). Similar proportions were home workers or civil servant, but it is to notice that all home workers were women, 35 of 175 (20.0\%), and all but one civil servant were men, 30 of 175 (17.1\%). Students were also represented, 25 of 175 $(14.3 \%)$ with a greatest proportion of women, $16(64.0 \%)$ than men, $9(36.0 \%)$.

At baseline, 19 of 175 patients (10.8\%) were under a first line ART while the other 156 (89.2 \%) were eligible for ART, stage 3 or 4 of the WHO clinical staging 2007 revision (www.who.int/hiv/pub/guidelines/HIVstaging150307.pdf). Twenty-nine of 175 (16.6\%) had a lymphocyte $\mathrm{CD}^{+}{ }^{+} \mathrm{T}$ cells count when entering the study. The median CD 4 count was 224 cells/ $\mu$ l, range (10-691). The main diagnosis for justifying hospitalization of patients was intestinal infection associated with diarrhea 
in 87 of 175 (49.7\%) followed by severe oral candidiasis (31.4\%), herpes zoster (20.5\%), malaria (18.3\%) and severe cutaneous mycosis (14.9\%). In case of clinical diarrhea, consistencies of feces were all abnormal, from pasty to watery stools. Watery stools, similar to those encountered in choleric patients, were found in 52 of $87(59.8 \%)$.

43 patients of the 175 ( $24.6 \%)$ were found to harbor an IP, and $27(15.4 \%)$ were infected with at least one opportunistic intestinal parasite (OIP). The prevalence rates of OIPs' were $9.7 \%(17 / 175)$ for Cryptosporidium sp., $5.1 \%$ (9/175) for Ent. bieneusi, $1.7 \%$ (3/175) for I. belli and $0.6 \%(1 / 175)$ for both Enc. intestinalis and Sarcocystis hominis. The other IP observed were also protozoan parasites, Entamoeba histolytica/Entamoeba dispar in nine cases (5.1\%) and G. intestinalis in three cases (1.7\%) but also helminths such as Ascaris lumbricoïdes in seven cases (4.0\%), hookworm in two cases (1.1\%), and Trichiuris trichiura, Enterobius vermicularis, Schistosoma mansoni in one patient each $(0.6 \%)$.

Considering the 87 patients with diarrhea, 23 (26.4\%) harbored an IP and 16 (18.4\%) were infected with an OIP. The OIP prevalence rates were then $12.6 \%(11 / 87)$ for Cryptosporidium spp., $4.6 \%$ (4/87) for Ent. bieneusi,
$3.4 \%(3 / 87)$ for $I$. belli, $1.1 \%$ (1/87) for Enc. intestinalis and $1.1 \%(1 / 87)$ for S. hominis. The others IP observed in that situation were $E$. bistolytica/E. dispar in four cases (4.6\%), A. lumbricoïdes in four cases (4.6\%) and G. intestinalis in two cases $(2.3 \%)$. The relationship between IP and diarrhea was not statistically significant for any parasite.

Concerning the techniques used for OIP identification in Kinshasa, as expected, only I. belli (the 3 cases) and the $S$. hominis case were detected by standard fecal examinations whereas Cryptosporidium spp and microsporidia species were only detected by dedicated techniques, MZNS and MTS/FFS respectively (Table I). Microsporidia species identification was performed using IFAT-MAbs in all cases.

The concordance between Kinshasa and Paris laboratories results was measured for the 43 positive samples and 26 of the negative samples randomly selected. The kappa value was 1, a perfect correlation, for all techniques (MRC, MZNS, MTS, IFAT-MAbs) except one since a false positive result was recorded for microsporidia using FFS in Paris (kappa value $=0.97$, IC95\% [0.91-1.00])

The specific PCR for Ent bieneusi and Enc intestinalis, performed in Paris, was positive for only three out of

\begin{tabular}{|c|c|c|c|c|c|c|c|}
\hline Patients n & Diarrhea yes & $\begin{array}{c}\text { Diarrhea } \\
\text { no }\end{array}$ & $\mathrm{DE}^{\curlywedge} \& \mathrm{MRCM}^{+}$ & MZNS $^{\star}$ & FFS $^{*}$ & MTS* & IFAT-MAb-Eb/E $\boldsymbol{i}^{*}$ \\
\hline 12 & 7 & 5 & - & Csp & - & - & - \\
\hline 7 & 2 & 5 & - & - & Msp & Msp & $\mathrm{Eb}$ \\
\hline 1 & 1 & - & - & - & Msp & Msp & $\mathrm{Ei}$ \\
\hline 1 & 1 & - & $\mathrm{Ib}$ & - & - & - & - \\
\hline 5 & 1 & 4 & $\mathrm{Eh} / \mathrm{Ed}$ & - & - & - & - \\
\hline 5 & 3 & 2 & $\mathrm{Al}$ & - & - & - & - \\
\hline 2 & 1 & 1 & Gi & - & - & - & - \\
\hline 2 & 1 & 1 & $\mathrm{Cm}$ & - & - & - & - \\
\hline 1 & - & 1 & Ank & - & - & - & - \\
\hline 1 & - & 1 & Al Ank & - & - & - & - \\
\hline 1 & 1 & - & $\mathrm{Eh} / \mathrm{Ed}$ & Csp & - & - & - \\
\hline 1 & 1 & - & Ib Sh Gi & Csp & Msp & Msp & $\mathrm{Eb}$ \\
\hline 1 & - & 1 & $\mathrm{Eh} / \mathrm{Ed}$ & Csp & - & - & - \\
\hline 1 & 1 & - & - & Csp & Msp & Msp & $\mathrm{Eb}$ \\
\hline 1 & 1 & - & $\mathrm{Eh} / \mathrm{Ed} \mathrm{Ev}$ & - & - & - & - \\
\hline 1 & 1 & - & Ib Sm & - & - & - & - \\
\hline 1 & 1 & - & $\mathrm{Eh} / \mathrm{Ed} \mathrm{Tt}$ & - & - & - & - \\
\hline 1 & 1 & - & $\mathrm{Al}$ & Csp & - & - & - \\
\hline 130 & 63 & 67 & - & - & - & - & - \\
\hline 175 & 87 & 88 & $3 \mathrm{Ib} ; 1 \mathrm{Sh}$ & 17 Csp & & & $9 \mathbf{E b}+1 \mathbf{E i}$ \\
\hline
\end{tabular}

${ }^{\wedge} \mathrm{DE}=$ Direct Examination; ${ }^{+} \mathrm{MRCM}=$ Modified Ritchie Concentration Method; ${ }^{\star}$ MZNS $=$ Modified Ziehl Neelsen Stain; ${ }^{*}$ FFS $=$ Fungi-Fluor Stain; ${ }^{*}$ MTS $=$ Modified Trichrome Stain; ${ }^{*}$ IFAT-MAbEb/Ei $=$ ImmunoFluorescence Antibody Test using monoclonal antibodies directed against Ent. bieneusi or E. intestinalis

Eh/Ed: Entamoeba histolytica / Entamoeba dispar; Cm: Chilomastix mesnili; Al: Ascaris lumbricoïdes; Gi: Giardia intestinalis; Sm: Schistosoma mansoni; Ev: Enterobius vermicularis; Tt: Trichuris trichiura; Ank: Ankystoma sp.; Csp: Cryptosporidium sp.; Msp: microsporidia species; Eb: Enterocytozoon bieneusi; Ei: Encephalitozoon intestinalis; Ib: Isospora belli; Sh: Sarcocystis hominis

Table I. - Diagnosis of intestinal parasites in optic microscopy in 175 hospitalized AIDS patients in four hospitals in Kinshasa (DRC). 
the ten samples positive by microscopic methods, because of PCR inhibition probably due to the formalin addition. Among these samples, only two ITS sequences could be obtained (samples RDC69 and RDC71) for genotyping. Both sequences were $100 \%$ identical to genotype NIA1 (Espern et al., 2007).

\section{DISCUSSION}

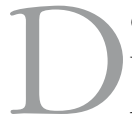
emographic and clinical data from this study were similar to those reported among African AIDS patients, in particular the predominant heterosexual transmission ( $\operatorname{sex}$ ratio $\mathrm{M} / \mathrm{F}=0.97$ ), and comparable occupational behavior (Same-Ekobo et al., 1997). The fact that very few of those patients, 19 $(10.8 \%)$ and $29(16.6 \%)$ out of 175 , were respectively under ART or with a previous result of $\mathrm{CD}^{+}$cell count at the moment of their hospitalization was not surprising since most of them were diagnosed AIDS on that occasion. The prevalence of OIP (15.4\%), as determined by the results of the screening, is globally on the range of results previously reported in other studies conducted in Africa on AIDS patients. In detail, the $9.7 \%$ prevalence rate of Cryptosporidium sp. was slightly higher than the rates reported from four studies in Kenya, Zimbabwe, Zambia and Cameroun, similar to that reported in one study from Senegal, but lower than the 16-41\% prevalence rates reported from many sub-Saharan countries (Gassama et al., 2001; Same Ekobo et al., 1997; Adjei et al., 2003; Fisseha et al., 1998; Gatei et al., 2006; Houpt et al., 2005; Khumalo-Ngwenya et al., 1994; Maiga et al., 2002; Mengesha et al., 1994; Mwachari et al., 1998; Sarfati et al., 2006; Simango et al., 2004; Tadesse et al., 2005; Tumwine et al., 2005; Cegielski et al., 1999; Dieng et al., 1994). The difference is more contrasted with microsporidia (5.7\%), and I. belli (1.7\%) in comparison with the 9.4-31.3\% range for microsporidia and 4.4-15\% range for $I$. belli observed in many African countries (Gassama et al., 2001; Khumalo-Ngwenya et al., 1994; Tumwine et al., 2005; Cegielski et al., 1999; Dieng et al., 1994; konate et al., 2005; Lebbad et al., 2001; Maiga et al., 1997; Same - Ekobo et al., 1997). However, recent studies in Central Africa (Cameroon and Gabon), using the same methods for diagnosis and without selection of patients based on clinical criteria, also reported low prevalence rates, lower than $6 \%$ for microsporidia and lower than $3 \%$ for I. belli (Breton et al., 2007; Sarfati et al., 2006). Multiple OIP infections were seen in five of the 27 patients with OIP (18.5\%) while co-infections with other parasites were present in four of 27 (14.8\%) (Table I). Concerning diarrhea, the $49.7 \%$ prevalence found in this study is in the range of recent comparable studies conducted in Senegal (49.7 \%) Malawi (48.8\%) and Ethiopia (45.2\%) (Gassama et al., 2001; Ngoma et al., 2008; Assefa et al., 2009). In a recent study in Malawi, van Oosterhout et al., report a $56 \%$ person year incidence of digestive illness among 660 AIDS patients, $95 \%$ before starting on ART (van Oosterhout et al., 2005). But surprisingly, we found no association between the presence of IP in stools and diarrhea. In detail, 11 out of the 27 OIP infected patients, more than $40 \%$, were harboring OIP without digestive symptoms at admission. Those correspond to 6 of 17 (35.3\%) Cryptosporidium spp. and five of nine (55.6\%) Ent. bieneusi infections. In contrast, the three patients with I. belli infections were all diarrheic. The situation was not different considering the other IP since one out of three $(33.3 \%)$ patients infected with $G$. intestinalis and four out of nine (44.4\%) patients infected with $E$. histolytica / E. dispar were also non diarrheic. It is noteworthy that in this study diarrhea couldn't be linked to any intestinal parasite in more than $70 \%$ of the cases. Unfortunately, diagnosis of bacteria and viruses couldn't be investigated. In comparison, Gassama et al. in Senegal found that the more frequent pathogens were enteroaggregative E. coli (19.6\%), microsporidia (9.4\%), Cryptosporidium sp. (8.2\%), rotavirus (8.2\%), Shigella sp. (7.6 \%), Candida albicans (7.6\%) and Isospora belli (4.4\%) (Gassama et al., 2001). One explanation could be a higher CD4 cell count level in our population study. Unfortunately we cannot cross that information since the CD 4 cell count couldn't be performed in this study. Nevertheless, according to WHO clinical staging, our population study appears to be very immunocompromised since all our patients were classified stage 3 or 4. Two other explanations appears to be more convincing, firstly a defect of power in statistical analysis, because of a too small population sample, and secondly, the abilities of species genotypes of Cryptosporidium spp. or the microsporidia to induce or not a pathology in man. It is well known now that, even in very immunocompromised patients, the clinical forms of OIP are very diverse in man, varying from a moderate digestive embarrassment to a severe digestive pathology with weight loss and profound fatigue (Bern et al., 2005; Cama et al., 2007). The pathogenic capacity of Ent. bieneusi in particular has been questioned since some authors found no association between intensity of microsporidia infection and clinical symptoms (Clarridge et al., 1996; Rabaneck et al., 1993). It has been recently reported in Peru that only some Ent bieneusi or C. parvum or C. hominis genotypes presents a statistically significant association with diarrhea (Bern et al., 2005; Cama et al., 2007). In our study, because of prolonged conservation in formalin, samples containing Ent. bieneusi spores were positive in PCR only in three out of nine $(33.3 \%)$ and genotype available in only two. Those two genotypes obtained from patients without diarrhea were both of type NIA1 (Espern et al., 2007). Interestingly, that genotype, found previously in 
Africa in human in Niamey (Niger), belongs to sub group 1c, and is very close to genotypes A (Peru1) and $\mathrm{K}$ (Peru2), one base pair difference, for which were found no association with chronic diarrhea in Bern et al. study. So these results highlight the need for systematic genotyping to clarify the relationship between OIP genotype and symptomatic infections.

Globally, and despite a lack of some information's in our study, such as lymphocytes CD4 cell count, our results confirm that parasite intestinal infections are a major concern for AIDS patients, especially when starting ART. A main result was the demonstration that in hospitalized symptomatic AIDS patients, intestinal parasitic infections can go unrecognized since up to $45 \%$ of patients with intestinal parasite were non diarrheic. It might have long-lasting consequences not only for the individual AIDS patient who is undergoing ART, whose life is at risk, but also for the communities among whom uncontrolled pathogens can spread (crowded conditions or institutions such as hospitals or day care centers). Therefore, due to the absence of clinical markers, routine stool examination for intestinal parasite but also stains designed for Cryptosporidium spp. or the microsporidia diagnosis are of critical importance in AIDS patients, especially when undergoing ART.

\section{ACKNOWLEDGEMENTS}

his work was supported by a grant funded by the Institut de Médecine et d'Épidémiologie Appliquée (IMEA) Fondation Internationale Léon MBA (IMEA/5977WUM90). We also thank Dr J.C. Drapier (CNRS UPR 2301) for financial support with initial ITS sequencing. The funders had no role in study design, data collection and analysis, decision to publish, or preparation of the manuscript.

\section{REFERENCES}

Accoceberry I., Thellier M., Desportes-Livage I., Achbarou A., Biligui S., Danis M. \& Datry A. Production of monoclonal antibodies directed against the microsporidium Enterocytozoon bieneusi. J. Clin. Microbiol.,1999, 37, 4107-4112.

Adjei A., Lartey M., Adiku T.K., Rodrigues O., Renner L., Sifah E., Mensah J.D., Akanmori B., Otchere J., Bentum B.K. \& Bosompem K.M. Cryptosporidium oocysts in Ghanaian AIDS patients with diarrhoea. East. Afr. Med. J., 2003, 80, 369-372.

Alfa Cisse O., Ouattara A., Thellier M., Accoceberry I., Biligui S., Minta D., Doumbo O., Desportes-Livage I., Thera M.A., DANIS M. \& DATRY A. Evaluation of an immunofluorescentantibody test using monoclonal antibodies directed against Enterocytozoon bieneusi and Encephalitozoon intestinalis for diagnosis of intestinal microsporidiosis in Bamako (Mali). J. Clin. Microbiol., 2002, 40, 1715-1718.
ANONymous WHO. Case definitions of HIV for surveillance and revised clinical staging and immunological classification of HIV-related disease in adults aged 15 years or older. SEARO Publication on HIV/AIDS, 2006.

Assefa S., Erko B., Medhin G., Assefa Z. \& Shimelis T. Intestinal parasitic infections in relation to HIV/AIDS status, diarrhea and CD4 T-cell count. BMC Infect. Dis., 2009, 9, 155.

Bern C., Kawai V., Vargas D., Rabke-Verani J., Williamson J., Chavez-Valdez R., Xiao L., Sulaiman I., Vivar A., Ticona E., Navincopa M., Cama V., Moura H., Secor W.E., Visvesvara G. \& Gilman R.H. The epidemiology of intestinal microsporidiosis in patients with HIV/AIDS in Lima, Peru. J. Infect. Dis., 2005, 191, 1658-1664.

Breton J., Bart-Delabesse E., Biligui S., Carbone A., Seiller X., Okome-Nkoumou M., Nzamba C., Kombila M., Accoceberry I. \& Thellier M. New highly divergent rRNA sequence among biodiverse genotypes of Enterocytozoon bieneusi strains isolated from humans in Gabon and Cameroon. $J$. Clin. Microbiol., 2007, 45, 2580-2589.

Cama V.A., Ross J.M., Crawford S., Kawai V., Chavez-Valdez R., Vargas R., Vivar A., Ticona E., Navincopa M., Williamson J., Ortega Y., Gilman R.H., Bern C. \& Xiao L. Differences in clinical manifestations among Cryptosporidium species and subtypes in HIV-infected persons. J. Infect. Dis., 2007, 196, 684-691.

Cegielski J.P., Ortega Y.R., McKee S., Madden J.F., Gaido L., Schwartz D.A., Manji K., Jorgensen A.F., Miller S.E., Pulipaka U.P., Msengi A.E., Mwakyusa D.H., Sterling C.R. \& Reller L.B. Cryptosporidium, Enterocytozoon, and Cyclospora infections in pediatric and adult patients with diarrhea in Tanzania. Clin. Infect. Dis., 1999, 28, 314-321.

Clarridge J.E., $3^{\text {RD }}$, Karkhanis S., Rabeneck L., Marino B. \& FoOTE L.W. Quantitative light microscopic detection of Enterocytozoon bieneusi in stool specimens: a longitudinal study of human immunodeficiency virus-infected microsporidiosis patients. J. Clin. Microbiol., 1996, 34, 520-523.

Coyle C.M., Wittner M., Kotler D.P., Noyer C., Orenstein J.M., TANOwitz H.B. \& WeIss L.M. Prevalence of microsporidiosis due to Enterocytozoon bieneusi and Encephalitozoon (Septata) intestinalis among patients with AIDS-related diarrhea: determination by polymerase chain reaction to the microsporidian small-subunit rRNA gene. Clin. Infect. Dis., 1996, 23, 1002-1006

Dieng T., Ndir O., Diallo S., Coll-Seck A.M. \& Dieng Y. Prévalence de Cryptosporidium sp. et d'Isospora belli chez des patients atteints du syndrome d'immunodéficience acquise (SIDA) à Dakar (Sénégal). Dakar Med., 1994, 39, 121-124.

Dillingham R.A., Pinkerton R., Leger P., Severe P., Guerrant R.L., Pape J.W. \& Fitzgerald D.W. High early mortality in patients with chronic acquired immunodeficiency syndrome diarrhea initiating antiretroviral therapy in Haiti: a casecontrol study. Am. J. Trop. Med. Hyg., 2009, 80, 1060-1064.

Espern A., Morio F., Miegeville M., Illa H., Abdoulaye M., Meyssonnier V., Adehossi E., Lejeune A., Cam P.D., Besse B. \& GAY-Andrieu F. Molecular study of microsporidiosis due to Enterocytozoon bieneusi and Encephalitozoon intestinalis among human immunodeficiency virus-infected 
patients from two geographical areas: Niamey, Niger, and Hanoi, Vietnam. J. Clin. Microbiol., 2007, 45, 2999-3002.

Fisseha B., Petros B. \& WoldeMichael T. Cryptosporidium and other parasites in Ethiopian AIDS patients with chronic diarrhoea. East. Afr. Med. J., 1998, 75, 100-101.

Gassama A., Sow P.S., Fall F., Camara P., Gueye-N'diaye A., Seng R., Samb B., M'Boup S., Aïdara-Kane A. ET al. Ordinary and opportunistic enteropathogens associated with diarrhea in Senegalese adults in relation to human immunodeficiency virus serostatus. Int. J. Infect. Dis., 2001, 5, 192-198.

Gatei W., Wamae C.N., Mbae C., Waruru A., Mulinge E., Waithera T., Gatika S.M., Kamwati S.K., Revathi G., Hart C.A. ET AL. Cryptosporidiosis: prevalence, genotype analysis, and symptoms associated with infections in children in Kenya. Am. J. Trop. Med. Hyg., 2006, 75, 78-82.

Henriksen S.A. \& Pohlenz J.F. Staining of cryptosporidia by a modified Ziehl-Neelsen technique. Acta. Vet. Scand., 1981, 22, 594-596.

Houpt E.R., Bushen O.Y., Sam N.E., Kohli A., Asgharpour A., Ng C.T., Calfee D.P., Guerrant R.L., Maro V., Ole-Nguyaine S. \& SHAO J.F. Short report: asymptomatic Cryptosporidium bominis infection among human immunodeficiency virusinfected patients in Tanzania. Am.J. Trop. Med. Hyg., 2005, 73, 520-522.

Katzwinkel-Wladarsch S., Lieb M., Helse W., Loscher T. \& RINDER H. Direct amplification and species determination of microsporidian DNA from stool specimens. Trop. Med. Int. Health., 1996, 1, 373-378.

Konate A., Minta D., Diarra M., Dolo A., Dembele M., Toure C., Kalle A., Traore H. \& Maiga M. Parasitoses digestives au cours de la diarrhée du sida. Bull. Soc. Pathol. Exot., 2005, 98, 33-35.

Khumalo-NGwenya B., Luo N.P., Chintu C., Sunkutu R., SaKalaKazembe F., Baboo K.S., Mathewson J., Zumla A. ET al. Gut parasites in HIV-seropositive Zambian adults with diarrhoea. East. Afr. Med.J., 1994, 71, 379-383.

LaWn S.D., Harries A.D., ANGlaret X., MYer L. \& WoOd R. Early mortality among adults accessing antiretroviral treatment programmes in sub-Saharan Africa. AIDS., 2008, 22, 1897-1908.

Lebbad M., Norrgren H., Naucler A., Dias F., Andersson S. \& LINDER E. Intestinal parasites in HIV-2 associated AIDS cases with chronic diarrhoea in Guinea-Bissau. Acta Trop., 2001, $80,45-49$

Macpherson P., Moshabela M., Martinson N. \& Pronyk P. Mortality and loss to follow-up among HAART initiators in rural South Africa. Trans. R. Soc. Trop. Med. Hyg., 2008, 103 (6), 588-593.

Maiga M.Y., Dembele M.Y., Traore H.A., Kouyate M., Traore A.K., Maiga I.I., Bougoudogo F., Doumbo O. \& Guindo A. Manifestations digestives du Sida chez l'adulte au Mali. Bull. Soc. Pathol. Exot., 2002, 95, 253-256.

Maiga I., Doumbo O., Dembele M., Traore H., Desportes-Livage I., Hilmarsdottir I., Giboyau E., Maiga L., Kassambara L., El FAKHrY Y., Datry A., Gentilini M. \& Pichard E. Microsporidiose intestinale humaine à Bamako (Mali): Présence d'Enterocytozoon bieneusi chez les patients séropositifs pour le
VIH. Cabiers d'Étude et de Recherches Francophones/Santé, 1997, 7, 257-262.

Mengesha B. Cryptosporidiosis among medical patients with the acquired immunodeficiency syndrome in Tikur Anbessa Teaching Hospital, Ethiopia. East. Afr. Med. J., 1994, 71, 376-378.

Mwachari C., Batchelor B.I., Paul J., Waiyaki P.G. \& Gilks C.F. Chronic diarrhoea among HIV-infected adult patients in Nairobi, Kenya. J. Infect., 1998, 37, 48-53.

Mzileni M.O., Longo-Mbenza B. \& Chephe T.J. Mortality and causes of death in HIV-positive patients receiving antiretroviral therapy at Tshepang Clinic in Doctor George Mukhari Hospital. Pol. Arch. Med. Wewn., 2008, 118, 548-554.

Ngoma D., Makombe S.D., Kamoto K. \& Harries A.D. World Health Organization Clinical Stage 3 disease conditions in HIV-infected patients who start antiretroviral therapy in Malawi. Trop. Doct., 2008, 38, 159-160.

Rabeneck L., Gyorkey F., Genta R.M., Gyorkey P., Foote L.W. \& RISSER J.M. The role of Microsporidia in the pathogenesis of HIV-related chronic diarrhea. Ann. Intern. Med., 1993, 119, 895-899.

RitchiE L.S. An ether sedimentation technique for routine stool examinations. Bull. U.S. Army Med. Dep., 1948, 8, 326.

Same-Еково A., Lohoue J. \& Mbassi A. Étude clinique et biologique des diarrhées parasitaires et fongiques chez les sujets immunodéprimés dans la zone urbaine et périurbaine de Yaoundé. Cabiers d'Étude et de Recherches Francophones / Santé, 1997, 7, 349-354.

Sarfati C., Bourgeois A., Menotti J., Liegeois F., Moyou-Somo R., Delaporte E., Derouin F., Ngole E.M. \& Molina J.M. Prevalence of intestinal parasites including microsporidia in human immunodeficiency virus-infected adults in Cameroon: a cross-sectional study. Am.J. Trop. Med. Hyg., 2006, 74, 162-164.

Sewankambo N.K., Gray R.H., Ahmad S., SERWadda D., WabWireMangen F., Nalugota F., Kiwanuka N., Lutalo T., Kigozi G., Li C., Meehan M.P., Brahmbatt H. \& Wawer M.J. Mortality associated with HIV infection in rural Rakai District, Uganda. AIDS., 2000, 14, 2391-2400.

Simango C. \& Mutikani S. Cryptosporidiosis in Harare, Zimbabwe. Cent. Afr. J. Med., 2004, 50, 52-54.

TADesse A. \& Kassu A. Intestinal parasite isolates in AIDS patients with chronic diarrhea in Gondar Teaching Hospital, North west Ethiopia. Ethiop. Med.J., 2005, 43, 93-96.

Thellier M., Biligui S., Desportes-Livage I., Accoceberry I. \& Datry A. Monoclonal antibody enabling the diagnosis of Encephalitozoon intestinalis in fecal specimens: importance of the mode of selection of hybridomas. J. Eukaryot. Microbiol., 2001, Suppl., 71S-72S.

Thellier M. \& Breton J. Enterocytozoon bieneusi in human and animals, focus on laboratory identification and molecular epidemiology. Parasite, 2008, 15, 349-358.

Tumwine J.K., Kekitinwa A., Bakeera-Kitaka S., Ndeezi G., Downing R., Feng X., Akiyoshi D.E. \& Tzipori S. Cryptosporidiosis and microsporidiosis in ugandan children with persistent diarrhea with and without concurrent infection 
with the human immunodeficiency virus. Am.J. Trop. Med. Hyg., 2005, 73, 921-925.

van Gool T., Canning E.U. \& Dankert J. An improved practical and sensitive technique for the detection of microsporidian spores in stool samples. Trans. R. Soc. Trop. Med. Hyg., 1994, 8, 189-190.

van Oosterhout J.J., Bodasing N., Kumwenda J.J., Nyirenda C., Mallewa J., Cleary P.R., De BaAr M.P., Schuurman R., Burger D.M. \& ZijLSTRA E.E. Evaluation of antiretroviral therapy results in a resource-poor setting in Blantyre, Malawi. Trop. Med. Int. Health., 2005, 10, 464-470.

Weber R., Bryan R.T., Owen R.L., Wilcox C.M., Gorelkin L. \& VISVESVARA G.S. Improved light-microscopical detection of microsporidia spores in stool and duodenal aspirates. The Enteric Opportunistic Infections Working Group. N. Engl. J. Med., 1992, 326, 161-166.

Weiss L.M., Zhu X., Cali A., Tanowitz H.B. \& Wittner M. Utility of microsporidian rRNA in diagnosis and phylogeny: a review. Folia Parasitol. (Praha), 1994, 41, 81-90.

Wumba R., Enache-Angoulvant A., Develoux M., Mulumba A., Mulumba P.M., Hennequin C., Odio T.W., Biligui S., Sala J. \& ThelLIER M. Prévalence des infections opportunistes digestives parasitaires à Kinshasa (République Démocratique du Congo), résultats d'une enquête préliminaire chez 50 patients au stade sida. Med. Trop., 2007, 67, 145-148.

Zachariah R., Fitzgerald M., Massaquoi M., Pasulani O., ARnould L., MaKombe S. \& Harries A.D. Risk factors for high early mortality in patients on antiretroviral treatment in a rural district of Malawi. AIDS, 2006, 20, 2355-2360.

Zhu X., Wittner M., Tanowitz H.B., Kotler D., Cali A. \& WeIss L.M. Small subunit rRNA sequence of Enterocytozoon bieneusi and its potential diagnostic role with use of the polymerase chain reaction. J. Infect. Dis., 1993, 168, 1570-1575.

Zhu X., Wittner M., Tanowitz H.B., Cali A. \& Weiss L.M. Nucleotide sequence of the small subunit rRNA of Septata intestinalis. Nucleic Acids Res., 1993, 21, 4846.

Reçu le 5 mai 2010 Accepté le 18 juin 2010 